\title{
Relationship Between the Police Educational Formation System and Public Security
}

\author{
Msc. Artur Beu ${ }^{1}$, Doc. Ariana Nepravishta ${ }^{2}$,
}

\begin{abstract}
:
The harmonization between the Albanian police education system and the European Framework and in particular with the Bologna System is a must of nowadays and for the police organization itself. In this context, the police organization needs to be upgrade especially in the upper level but it can't be understood without an adequate educational system. Currently, the challenges of the police education system face some obstacles of formation type which lead to a lack in the police education to achieve university levels. This will return into a boomerang for the forthcoming generations which are being prepared to be police staff, due to the lack of relevant university education. Based on the current education model, a police officer recruit has the opportunity to joint police organization after the high school (18 years old), and his education level is destined to be not upgraded in any way in order to reach university levels. It seems that Albania has so much need to an escalation process when it comes to the police education system that it can accept a missing formation which could lead to real problems in the near future. This type of model could function in the basic operational level but it is destined to malfunction in the upper level of leadership. In this contexts it is needed a parallel university education level associated to the police education formation in order to upgrade the police leadership. Currently, there is no experience of cooperation between universities and police formation institution in this regard. In Europe and other countries of the Region the main goal is the unification of curricula in order to have some common core curricula and in this manner to improve the mutual exchange of students and cadets from one to another institution and from one to another country. This is absolutely achievable also in police education and formation framework. A more effective cooperation and exchange process of students among police academies and formation centers in Europe and region will enable a more effective fight against crime and will lead to the so desirable product of enhancement of public trust towards police and an increase of the perception of security.
\end{abstract}

Key words: Common curricula, education system, leadership, public security. 


\section{Introduction}

In the last two decades due to social problematic transition of our country, urban safety and security was subject to many changes with high intensity which undermined it in profundity.

Urban safety and security theme were presented to the Albanian public only during these last decades compared to other Western European countries. Various kinds of politics related to it have their insecurity features and are influenced by an inverse relationship that regulates criminal offences with the relative "social alarm" that follows provoked by the capacity to be conditioned by media in structuring and drafting the agenda to be implemented. The complexity of issues related to urban insecurity phenomenon brings to the development of a governance of a multilevel kind and the awareness of the existence of polyhedral realties which it is not possible to be faced by traditional tools as well as policy strategies, but should be integrated by an active participation of local actors able to understand citizen's fears and have the capacity of finding effective solutions.

The presence of some public and private entities able to influence on the decisions process phases generates a fragmentation of competencies that brings to some public policies which are a consequence of multilateral forms among different levels of various entities, reducing the monopole of the state toward safety and security. Thus, we are in front of a passage from the state to understanding. The biggest threat is dictated from the referral or implementation of some rapid policies characterised exclusively by symbolic nature, unable to intervene broadly and effectively in a certain territorial context.

Starting from the last reforms related to safety and security policies implemented, there are some deficiencies evidenced in "the Albanian safety and security model" without a specific national policy that brings safety and security structured in a solid and shared manner. The complexity of the problem leads to integrated nature policies which aim at cooperation between State and local Governments sharing the same finalities, i.e. liveability and accessibility of urban contexts. To understand the contractual policies evolution related to urban safety and security in the Albanian reality and above all in an urban context it is necessary a study on problematic as well as a local reality study, specifically of Tirana because of its metropolitan nature where we can find all types of safety and security problems.

Education and training are considered as the mirror of the society, showing in these way strengthnesses, weaknesses, hopes, prejudices and main values of its culture (Kirk \& Gallagher 1983). They play a determining role in the professional and development personal of people because they are the real asset of a country which is considered as developing focus. Education and training play a 
fundamental role in assisting an individual and the society to improve social, economic and cultural changes as well as to promote the development of human capital which is crucial for the economic growth. Modern education, especially in the school, aims at acquiring of knowledge, capabilities and behavior required to the youth in order to be functional in the society. Schools become in this way agents which offer development of civilization within the society (Pandey 1996). Essentially, schools are institutions, where atudents learn to evaluate what the society requires to contribute for its advancement and development.

A key point related to this issue is the actual Law No. 9749 "Law on the state police" dated $4^{\text {th }}$ of June 2007 which has brought essential changes in state police structure. Actually, in Albania does not exist a Police Academy (as an academic institution) anymore, which is not the right approach having into account the Albanian framework. Due to the radical changes of our society, the majority of public institutions were subject of reformation and the police Academy was not out of target.

The Albanian State Police is a Law Enforcement Organization. It is structured based on two levels. At central level there is the General Directorate of State Police and at local level it is divided in 12 District Police Directorates as well as 8 Regional Directorates for the Border and Migration.

The General Directorate of State Police is structured based on five departments, respectively on Public Order and security Department; Border and Migration Department; Serious Crime and Organized Crimes Department; Support Services Department and Police Training Department, as well as other four central directorates under direct dependence of the Director General of the State Police .

The responsible structure on education and training is the Police Training Department which it is composed by two main pillars the Directorate of Police Education and Police Formation Centre.

The actual model into force is based on a six months course followed by a period of twenty weeks of practice. The teaching of curricula for the "General Patrol" is based on modules. There are 7 modules which are delivered over 20 weeks of theory and 20 weeks of practice (in the field). More concretely:

$\begin{array}{llrl}\text { 1. } & \text { General Policing } & 372 & \text { hours } \\ \text { 2. } & \text { Operational police skills } & 134 & \text { hours } \\ \text { 3. } & \text { Computer-Internet } & 35 & \text { hours } \\ \text { 4. } & \text { Foreign language } & 28 & \text { hours } \\ \text { 5. } & \text { Physical Training } & 32 & \text { hours } \\ \text { 6. } & \text { First Aid } & 25 & \text { hours } \\ \text { 7. } & \text { Fire arms } & 71 & \text { hours }\end{array}$

Field training includes 715 hours and the total of all the course is 1430 hours. 
Firstly, this kind of model, "learning by doing" if remains the only police educative institution, is destined to malfunction because of the lack of a basic core police education of new police officers. It is not possible considering such an approach when it comes to fight criminality and protect people. A good law enforcement officer must know how to protect himself and the others or better he must know how to enforce the law.

Studies and research related to hearing skills showed that: $70 \%$ of the time of an individual, exept bed time, it is passed comunicating.

\section{In the whole time consumed by a person comunicating, it is descovered that:}

- $45 \%$ of time is spent hearing.

- $30 \%$ of time is spent speaking.

- $16 \%$ of time is spent reading.

- $9 \%$ of time is spent writting.

Police officers have more necessity to take information than to give it. The most part of time is passed taking information. They take information during interviews, scene of crime, patrolling and in most cases where it is requested accurate control and hearing the more active and effective it is possible.

A police officer with a basic education of high school which is the main request of being selected at the police educational forming centre course, after passing positively the basic course is, according to the actual model, ready to be insert into the police forces for the second period of 20 months in the field. After this second period the new police officer should attend a period of three years in order to be able to attend the concourse of rank passing. Here below you could find the passages in the new rank system:
- Inspector
1 Year and 4 months
- Chief-inspector
2 years and 8 months
- Sub-commissar
- Commissar
4 Years
6 Years
- Chief-commissar
8 Years
- Leader
10 Years
- $\quad$ First Leader
12 Years and 8 months
Deputy/Director
15 Years and 4 months

\section{The European perspective and possible findings}

Albania aims at the European Union accession as soon as it is possible. This means that Albania should meet European standards in all fields including police education. But, there are some problematic issues related to this. The first 
problem according to our opinion was presented above and it is connected to the model into force when it comes to the police education and formation system.

The enlargement of the European Union adds a number of challenges, opportunities and requirements to the work in the field of Vocational Education and Training (VET). The development of high quality vocational education and training is crucial and calls for further action to introduce instruments to ensure the transparency of diplomas and qualifications, including promoting action quite similar to the Bologna-process, but adapted to the field of VET.

According to the "Copenhagen Declaration" strategies for lifelong learning and mobility are essential to promote employability, active citizenship, social inclusion and personal development. The following Copenhagen Declaration main priorities are challenges for the police officer's basic education. These challenges can be met by the implementation of a Common Core Curriculum. But, the implementation of the Common Curriculum need the reintroduction of the Police Academy based on at least three-years attendance, in order to be in line with Bologna-process and the Copenhagen Declaration.

The priorities of the Copenhagen Declaration are as follows:

1. Strengthening the European dimension in vocational education and training with the aim of improving closer cooperation in order to facilitate and promote mobility and the development of inter-institutional cooperation, partnerships and other transnational initiatives, all in order to raise the profile of the European education and training area in an international context so that Europe will be recognised as a world-wide reference for learners.

2. Increasing transparency in vocational education and training through the implementation and rationalisation of information tools and networks, including the integration of existing instruments such as the European CV, certificate and diploma supplements, the Common European framework of reference for languages and the EUROPASS into one single framework.

3. Strengthening policies, systems and practices that support information, guidance and counselling in the Member States, at all levels of education, training and employment, particularly on issues concerning access to learning, vocational education and training, and the transferability and recognition of competences and qualifications, in order to support occupational and geographical mobility of citizens in Europe.

4. Investigating how transparency, comparability, transferability and recognition of competences and/or qualifications, between different countries and at different levels, could be promoted by developing reference levels, common principles for certification, and common measures, including a credit transfer system for vocational education and training that could be compatible with the existing European Credit Transfer System in higher education. 
5. Increasing support to the development of competences and qualifications at sectoral level, by reinforcing cooperation and co-ordination especially involving social partners. Several initiatives on a community, bilateral and multilateral basis, including those already identified in various sectors aiming at mutually recognised qualifications, illustrate this approach.

6. Developing a set of common principles regarding validation of non-formal and informal learning with the aim of ensuring greater compatibility between approaches in different countries and at different levels.

7. Promoting cooperation in quality assurance with particular focus on exchange of models and methods, as well as common criteria and principles for quality in vocational education and training.

8. Giving attention to the learning needs of teachers and trainers within all forms of vocational education and training.

On the basis of these priorities the aim has been not only to create a shared vision of vocational education and training in Europe but also to increase voluntary cooperation in VET.

In 1999, 29 European Ministers in charge of higher education signed in Bologna the Declaration on establishing the European Area of higher education by 2010 and promoting the European System of higher education world-wide. The ministers affirmed in the Declaration their intention to:

1. adopt a system of easily readable and comparable degrees,

2. adopt a system with two main cycles (undergraduate / graduate),

3. establish a system of credits (such as ECTS),

4. promote mobility by overcoming obstacles,

5. promote European co-operation in quality assurance and

6. promote European dimensions in higher education.

In the following Prague meeting (2001), and also in those after it, the Ministers in charge of higher education of 33 European signatory countries reaffirmed their commitment to the objectives of the Bologna Declaration. In Prague they also emphasised lifelong learning, involvement of students, and enhancing the attractiveness and competiveness of the European Higher Education Area to other parts of the world (including the aspect of transnational education). At the moment the Bologna process is high on national and institutional agendas in all signatory countries.

After passing CCC basic education, a student is competent to continue in Bologna-process based higher education.

Sometimes there are discussions in vocational training about whether the theory should be taught before the practise or if it should be the other way around. The order is not crucial - the main thing is the link between theory and practice. Students should learn to combine theory and practise via their own actions. 
Expertise can only be developed if theory and practice are combined. In order to optimise learning, trainers should always ensure that training is designed to include both theory and practice.

Carrying out a function is not just about the work itself, but a result of learning at work and a reflection of one's own behaviour and performance. During the basic training students should learn that this reflection should focus not only on the task itself, but also on development of knowledge, values and assumptions. The development of students' reflective skills should play an essential role in basic training. After developing these reflective and cognitive skills a student will become a competent police officer responsible for their own self development. After the basic training we should have police officers who are able to carry out independently their basic tasks, who are evolving due to their experiences, and are becoming step by step more skilled workers moving towards being experts. Police officer basic training should achieve at least the same status of the vocational education and training (VET) programme, so that the student can have the opportunity of receiving a qualification with a public status.

The aim of police officer basic training is to provide national organisations with competent police officers, who have a good, basic level of knowledge and skills, in addition to having appropriate attitudes and values for their role.

After basic training a police officer should be able to maintain and update their knowledge and skills in different operational environments. They should have a positive and responsible attitude to their work and for their own development. The implementation of police higher education harmonized with that of our homologues, will bring important impacts:

- Gradual harmonisation of higher police education with other international Police Academies;

- Increase of performance and qualification of our cadets and especially of high ranks (leaders and first leaders);

- Motivation o f police officers to learn all the time and their introduction toward self learning study method;

- Development of rational and creative capabilities in applying contemporary techniques within police service and crime investigation.

- $\quad$ Preparation of a new police officer of 21-th century, who will be able to respond to the flexibility of the changes of psycho-social reality, market economy, social conflicts, etc.;

- Development of research capabilities of our cadets and employees in the field of policing in an independent manner; 
- $\quad$ Preparation of a police qualified elite and able to fulfil based on a high level professional culture institutional responsibilities;

- Creation of facilitation in the field of cooperation with foreign police forces and other police organizations in respect of formation and qualification of cadets;

- Facilitation of integration of Police Academy in the network of Police Academies.

Police education, training and research are integral part of didactics and are developed in order to respond to society needs on scientific knowledge.

In this context the Albanian State Police is committed to implement community policing philosophy. Community policing is foreseen by Law No. 9749 as one of the milestones of Albanian State Police. Our hypothesis is that of contributing in urban safety and security issues by undertaking a new approach concerning these problems, an anthropological approach, by adopting a proximity policing philosophy in the new Albanian context. As our neighbour countries of the European Union, we can mention Italy and France as well, the philosophy of community policing was converted in proximity policing that means a primary approach, a little step before passing to the community policing.

\section{A short description on Policing Community}

Policing community (PC) is a working philosophy and an organized strategy which it is considered as one of the contemporary methods of policing. This philosophy is essentially based on the faith that, people should cooperate within the process of policing and police should offer to them qualitative services as a return of their support to the police.

In addition, it is based on the faith that nowadays problems solution of the community requires the enhancement of the relationships between police and the community.

As many other organizations in the region, the State Police of Albania, these two last decades has encountered and it is making continuative efforts on policing community philosophy implementation. These efforts have been institutionalized by the above-mentioned Law on the State Police, as well as by the Strategy of the State Police 2007-2013.

Police education, training and research are integral part of didactics and are developed in order to respond to society needs on scientific knowledge.

In this context the Albanian State Police is committed to implement community policing philosophy. Community policing is foreseen by Law No. 9749 as one of the milestones of Albanian State Police. Our hypothesis is that of contributing in enhancing urban safety and security issues by undertaking a new approach 
concerning these problems, an anthropological approach, by adopting a proximity policing philosophy in the new Albanian context. As our neighbour countries of the European Union, we can mention Italy and France as well, the philosophy of community policing was converted in proximity policing that means a primary approach, a little step before passing to the community policing.

Proximity policing, in my opinion should be implemented through an operative approach inspired by updated requests to bring the police forces, through its police officers, closer to the citizens.

Proximity policing would bring physically closer this model which anyway should have its chameleonic feature in order to be in line with this changing Albanian social context, guaranteeing in this way communication forms as well as their coordination, including citizens to the "production" of urban safety and security processes.

Proximity policing embodies "participating safe and security" concept that lies beyond criminal offences of a certain importance, even including every day aspects that are subject to social peace field as well as the perception of safety and security themselves. Due to this fact, in this new society created as a reflection or a copy of western societies with their internal complexity, there is an effective need in the field of cooperation between private and public structures which would lead to the prevention of criminal offences simplifying or increasing police forces reaction. This is exactly the key point of our intervention trying to clarify the need of a primary step which means a proximity policing. Thus, it means a real cooperation of all relevant "social safety and security" institutions avoiding relevant territorial disaggregating in social preventive services and those delegated to the prevention and suppression of criminality (police forces including Municipal police forces with general competences, as well as Courts and Prefectures, too).

In addition, proximity policing parallel to the reintroduction of Police Academy will increase people's trust toward police forces.

Having such a contingent among police forces services the perception and sense of safety and security will increase without doubt.

Integrity, professionalism, cooperation and serious commitment on duty constitute some of the basic principles where police services are based on in order to fulfil their legal mission. In addition to these principles Community Policing is a complicated and multidimensional process which involves many concepts, principles and work procedures. It requires changes every year, at all police levels and in every field of its job. It requires a voluminous and insisting work.

Another key point according to us is the possible adoption of a parallel system of higher education based on universities partnership with the police education 
formation system. A better introduction of police cadets to non-military schools can be useful to bring them closer to students' thoughts. Currently, we have not registered any experience in this field which could help significantly in the increase of the trust of people.

Many countries in Europe and world have a Qualifications National Framework. These countries believe that the Framework ensures that qualifications should meet the economical and social demands of these countries and be at a good level of quality. It ensures flexibility and continuity for students and, the opportunity to be recognized internationally. The Framework is known as an important instrument which serves for the encouragement of Life Long Learning and ensures quality in education.

The European Union has presented its European Qualifications Framework (EQF). This enables all countries which have a National Qualifications Framework, to collate their qualifications using EQF as a "translator instrument"1.

European Qualification Framework was approved by the European Commission and adopted by the European Parliament in November 2007.

The official recommendations on EQF implementation entered into force in April 2008. The European Union has defined 2010 for the achievement of the required goal, in order to give the opportunity to the countries to be connected among each-other through the National Qualifications Framework and 2012 was the timeline to ensure individual qualifications certificates referred to EQF levels. 1

EQF includes a group of eight references levels with which it is possible to collate (so they can correspond) the National Framework levels, facilitating in this manner the comparison and recognition at all levels as well as personal and professional mobility of individuals. EQF is designed to include all types of general, vocational and higher qualifications.

Related to this issue there is also the possible exchange of police students between the different Academies in Europe or in the Region. In Europe and other countries of the Region the main goal is the unification of curricula in order to have some common core curricula and in this manner to improve the mutual exchange of students and cadets from one to another institution and from one to another country. This is absolutely achievable also in police education and formation framework. A more effective cooperation and exchange process of students among police academies and formation centers in Europe and region will enable a more effective fight against crime and will lead to the so desirable product of enhancement of public trust towards police and an increase of the perception of security.

\footnotetext{
${ }^{1}$ The European Qualifications Framework for lifelong learning (EQF)
} 
Being a guardian of the law it is not only a job. A law enforcement police officer is not there to judge if you are or are not a perpetrator according to his own verdict. Those who want to be part of this law enforcement organization should know that they are there as servants of the law, not to dictate it or judge about it. A reflection should be done in this context because it is not possible hearing by a police officer comments like this: when in front of an infringement of the traffic code, he was asked if he saw the car passing with the red light with high speed answered - yes, I saw it, but I don't want to stop it. Can you imagine he was in service in motorbike having a conversation with a friend of him in the middle of the street?

Our hypothesis is connected with an improvement on the basic education at all levels and especially in professional fields. It is through this also that a change is to be effected in the Morals of the People, calculated to reduce the number of acts of delinquency, and to lead the perpetrators gradually into the walks of innocence and sobriety.

\section{Conclusions:}

Responding to the needs of our society toward safety and security and public order, in the framework of globalisation it is not realizable without reforming police education system, aiming to come closer to international standards of our homologues;

Immediate needs to promote international standards and best practices of our homologues, especially toward the development of common curricula, interinstitutional cooperation, mobility schemes and integrated study programmes, training and research remain main priority;

Reformation and modernisation process of higher police education should aim at equivalence of diplomas, certifications or other academic recognitions of homologue academies and if possible all over the world;

An holistic approach by implementing proximity policing which means an operative approach inspired by updated requests in order to bring closer the police forces, through its police officers to citizens.

There is a real need of cooperation of all relevant "social safety and security" institutions avoiding relevant territorial disaggregating on social preventive services. This would be implemented converting municipal police duties in operational ones. Their competencies should be enlarged and upgraded in traffic regulation as well as offering all services related to registry office and supporting police forces by reporting all problematic which can lead to criminal behaviours. To understand the contractual policies evolution related to urban safety and security in the Albanian reality and above all in an urban context it is necessary a study on problematic as well as a local reality study, specifically of Tirana because 
of its metropolitan nature where we can find all types of safety and security problems.

The efficiency of the model depends on a cultural, technical and professional revolution of police forces. It is indispensable a flexible organisational structure, at least at the initial phase of proximity service as a basic precondition of the conceptual, organisational phase of the preventive policing service, contact orientated, opening in this way a communication channel with citizens.

An amendment of the Law no. 9749 "Law on the state police" dated $4^{\text {th }}$ of June 2007, by introducing the Police Academy by law as the only academic institution which would prepare skilled officers.

These changes will improve the law enforcement and will affect the morals of people increasing the perception toward safety and security.

In the close future, Police Academy should prepare not only high specialists, but first of all, the intellectual elite as leaders, managers and researchers to face future challenges and precede policing problems.

Police formation should be totally integrated with the need to fight organized crime, illegal trafficking, corruption, terrorism, etc. at national, international and transnational level.

\section{References}

Gagliardo Antonio, La sicurezza minacciata. Criminalità transnazionale e terrorismo nell'Europa di oggi - Editori Riuniti Marzo 2006

Selmini R. La sicurezza urbana, Editore: Il Mulino Marzo 2004

Ligji nr. 9749, datë 4.6.2007 për Policinë e Shtetit

Colquhoun Patrick March 21, 2011 A Treatise on the Police of the Metropolis -

Bibliothèque nationale de France

International conference: "Universita: IERI, OGGI, DOMANI" Tirana, 1315 November 2003

Indicators on institutional assessment and proposals on some qualitative standards in higher education. Botim i AAAL. Tirana, 2005.

Qualifications Framework for Lifelong Learning, August 2009.

The European Qualifications Framework for lifelong learning (EQF), Prill 2008.

CARDS VET project "Support to Vocational Education and Training Reform", 2008 